\title{
An Analysis of the Market Abuse Prohibition Enforcement in the United States of America
}

\author{
Howard Chitimira \\ LLB LLM LLD \\ Lecturer, Faculty of Law, North-West University \\ E-mail:Howard.Chitimira@nwu.ac.za
}

\section{Doi:10.5901/mjss.2014.v5n7p188}

\section{Abstract}

The United States of America (the US) has developed one of the most progressive and effective anti-market abuse enforcement frameworks in recent years. For example, at a federal level, its anti-market abuse enforcement framework involves self-regulatory organisations as well as private actions that enhance compliance with the law and facilitate the levying of sanctions against offenders. Put differently, rigorous enforcement is the key component of the US's market abuse regulation that makes it unique from similar regulation in other countries. Consequently, the US's anti-market abuse enforcement approaches have influenced the regulation of market abuse in a number of countries, including South Africa. Given this background, the detection, prosecution and enforcement measures adopted in the US will be briefly discussed and, where applicable, contrasted with similar enforcement methods in South Africa in order to recommend possible anti-market abuse enforcement measures that could be employed to increase the curbing of market abuse activities in South Africa. This is done by, first, examining the role of the United States Securities and Exchange Commission (the SEC) in relation to the enforcement of the market abuse prohibition in the US. Secondly, the role of the Department of Justice and the courts in relation to the enforcement of the market abuse ban in the US will be analysed. Lastly, a similar analysis in respect of other selected selfregulatory organisations will be undertaken.

Keywords: courts, insider trading, self-regulatory organisations, market abuse, market manipulation.

\section{Introduction}

The United States of America (the US) has developed one of the most progressive and effective anti-market abuse enforcement frameworks in recent years. ${ }^{1}$ For example, at a federal level, its anti-market abuse enforcement framework involves self-regulatory organisations as well as private actions that enhance compliance with the law and facilitate the levying of sanctions against offenders. ${ }^{2}$ Put differently, rigorous enforcement is the key component of the US's market abuse regulation that makes it unique from similar regulation in other countries. ${ }^{3}$ Consequently, the US's anti-market abuse enforcement approaches have influenced the regulation of market abuse in a number of countries, including South Africa. ${ }^{4}$ Given this background, the detection, prosecution and enforcement measures adopted in the US will be briefly discussed and, where applicable, contrasted with similar enforcement methods in South Africa in order to recommend possible anti-market abuse enforcement measures that could be employed to increase the curbing of market abuse ${ }^{5}$ activities in South Africa. ${ }^{6}$ This is done by, first, examining the role of the United States Securities and Exchange

\footnotetext{
${ }^{1}$ Steinberg "Insider Trading Regulation-A Comparative Perspective" 2003 The International Lawyer 153 169-171.

2 Steinberg 2003 The International Lawyer 169.

${ }^{3}$ Steinberg 2003 The International Lawyer 169. For related comparative analysis in other jurisdictions, see Bhattacharya \& Daouk "The World Price of Insider Trading" 2002 Journal of Finance 75 75-108; Lyon \& Du Plessis The Law of Insider Trading in Australia (2005) 159-168 \& Avgouleas The Mechanics and Regulation of Market Abuse: A legal and Economic Analysis (2005) 75-502.

${ }^{4}$ See Botha "Control of Insider Trading in South Africa: A Comparative Analysis" 1991 SA Merc LJ 1-18; Botha "Increased Maximum Fine for Insider Trading: A Realistic and Effective Deterrent?" 1990 SALJ 504-508; Chitimira The Regulation of Insider Trading in South Africa: A Roadmap for an Effective, Competitive and Adequate Regulatory Statutory Framework (2008) LLM dissertation, University of Fort Hare, 41-72.

${ }^{5}$ Refers to market manipulation and insider trading in this contribution.

${ }^{6}$ For related comments and discussion see Chitimira A Comparative Analysis of the Enforcement of Market Abuse Provisions (2012) LLD thesis, Nelson Mandela Metropolitan University, 230-257; Van Deventer "Anti-Market Abuse Legislation in South Africa" (10-06-2008) 1-5 <http://www.fsb.co.za/public/marketabuse/FSBReport.pdf> (accessed 05-05-2013); Myburgh \& Davis "The Impact of South Africa's Insider Trading Regime: A Report for the Financial Services Board" (25-03-2004) 8-33 <http://www.genesis-analytics.com/public/FSBReport.pdf> (accessed 09-02-2013); Chanetsa "Insider Trading is Notoriously Hard to Prosecute" Business Report 26 April 2004; Pretorius and Another v Natal South Sea Investment Trust 19653 SA 410 $(W)$, were the courts failed to convict the suspected insider trading offenders; Osode "The new South African Insider Trading Act: Sound law reform or legislative overkill?" 2000 Journal of African Law 239 239-263; Jooste "A critique of the insider trading provisions of the 2004 Securities Services Act" 2006
} 
Commission (the SEC) in relation to the enforcement of the market abuse prohibition in the US. Secondly, the role of the Department of Justice (the DOJ) and the courts in relation to the enforcement of the market abuse ban in the US will be analysed. Lastly, a similar analysis in respect of other selected self-regulatory organisations will be undertaken.

\section{Detection, Prosecution and the Enforcement of the Market Abuse Prohibition}

\subsection{The Role of the United States Securities and Exchange Commission}

The responsibility for civil and administrative enforcement of the market abuse prohibition rests primarily with the SEC. ${ }^{7}$ Nevertheless, the Commodity Futures Trading Commission (the CFTC) has the prerogative to oversee and enforce the prohibition relating to commodities derivatives and futures market abuse practices. ${ }^{8}$

Notwithstanding the fact that there are several other regulatory bodies, ${ }^{9}$ the SEC was established as an independent quasi-judicial and legislative regulatory board responsible for the enforcement of federal securities laws through the regulation of the stock market and securities industry in the US. ${ }^{10}$ The SEC's legislative powers include promulgating rules and regulations that have the force of law. ${ }^{11}$ The SEC may, for instance, issue interpretive letters and the so-called no-action letters to express its views and provide guidance to all the relevant persons regarding any market abuse violations. ${ }^{12}$ Moreover, the SEC's judicial functions include acting as an original tribunal regarding disciplinary actions against securities professionals subject to its supervision who violate securities laws or commit market abuse offences. ${ }^{13}$

In addition to its quasi-judicial and legislative functions, the SEC further exercises administrative and supervisory authority over the key participants in the securities industry to prevent and combat market abuse activities in the US.14 The SEC is also responsible for protecting investors, maintaining fair, orderly and efficient financial markets through facilitating capital formation and effectively enforcing securities laws to curb fraud, insider trading, market manipulation and other related market abuse practices. For purposes of effectiveness, the SEC is divided into four main divisions, namely the Corporate Finance, Market Regulation, Investment Management and Enforcement Divisions.

The Corporate Finance Division polices compliance with the mandatory disclosure requirement as well as registration by public companies of transactions such as mergers. It additionally operates an online Electronic Data Gathering Analysis and Retrieval system (the EDGAR system) to ensure equal access to non-public inside information for all relevant persons. This system has been successfully utilised to prevent possible insider trading and market manipulation in the US's financial markets. ${ }^{15}$

Moreover, the Market Regulation Division regulates the NYSE, the NASD, the MSRMB and other self-regulatory organisations. In relation to this, Market Regulation Division interprets any proposed changes to regulations, publicises investment-related topics for public education and monitors operations of the industry. In practice, the SEC delegates

\footnotetext{
SALJ 437 441-460; Van Deventer "New watchdog for insider trading" 1999 FSB Bulletin 2 3; Beuthin \& Luiz Beuthin's Basic Company Law (2000) 235-238; Luiz "Market Abuse and the Enforcement Committee" 2011 SA Merc LJ 151-172; Luiz "Insider Trading Regulation - If at First You Don't Succeed..." 1999 SA Merc LJ 136 136-151; Henning \& Du Toit "The Regulation of False Trading, Market Manipulation and Insider Trading" 2000 Journal for Juridical Science 155 155-165 \& Osode "The Regulation of Insider Trading in South Africa: A Public Choice Perspective" 1999 African Journal of International and Comparative Law 688 688-708.

${ }^{7}$ Ashe \& Counsell Insider Trading: The Tangled Web (1990) 7-12; Langevoort \& Gulati “The Muddled Duty to Disclose under Rule 10b-5” 2004 Vand L Rev 1639 1639-1680.

${ }^{8}$ For the purposes of this sub-heading, the discussion will be mainly focused on the roles of the SEC regarding the enforcement of the market abuse prohibition in the US. See further Avgouleas The Mechanics and Regulation of Market Abuse 104; 106.

${ }^{9}$ Such regulatory bodies include the CFTC and other self-regulatory organisations.

${ }^{10}$ Securities Exchange Act of 193415 USC 78i(a)(2)-(5) (2006) as amended by PL-111-257 (approved 05-10-2010), hereinafter referred to as the Securities Exchange Act, see s 4. Apart from enforcing the provisions of the Securities Exchange Act, the SEC enforces the relevant provisions of the Securities Act, the Trust Indenture Act of 1939, the Investment Company Act of 1940, the Investment Advisors Act of 1940, the Public Utility Holding Company Act of 1935, the Public Company Accounting Reform and Investor Protection Act of 2002 Public Law 107-204, 116 Stat 745 (as codified in scattered sections of 15; 28 USC), hereinafter referred to as the Sarbanes-Oxley Act and other related statutes. The SEC does not work in isolation. Other institutions under its authority include the New York Stock Exchange (the NYSE) as well as self-regulatory organisations like the National Association of Securities Dealers (the NASD) and the Municipal Securities Rule Making Board (the MSRMB). Palmiter Securities Regulation: Examples and Explanations (2005) $402-415$.

11 Ss 4; 4A \& 4C of the Securities Exchange Act, also see Hazen Federal Securities Law (2003) 4-7.

12 Generally see s 14(a) to (e) of the Securities Exchange Act. Also see Palmiter Securities Regulation 29; 415; 433-444.

${ }^{13}$ Furthermore, the SEC may act as an appellate tribunal to review disciplinary decisions or actions taken by the stock exchanges, the NASD and other selfregulatory organisations against their members. Palmiter Securities Regulation 29; 415; 433-444.

${ }^{14}$ Palmiter Securities Regulation 29.

15 The EDGAR system has been used in a number of instances to assess, review and obtain misleading, manipulative or deceptive information regarding any filings with the SEC. Palmiter Securities Regulation 31.
} 
most of its enforcement and rulemaking authority to the NYSE and the NASD. ${ }^{16}$ Notably, these two self-regulatory organisations merged to form the Financial Industry Regulatory Authority in 2007.17

The Investment Management Division oversees investment companies and their advisory professionals. It further administers federal security laws to improve the disclosure of non-public inside information and to minimise prejudice to investors without imposing an undue burden on regulated companies. Therefore, the SEC can interpret such laws and make rules to reduce the occurrence of market abuse practices in the relevant financial markets as much as possible. ${ }^{18}$

Likewise, the Enforcement Division investigates any violation of the laws and rules that govern insider trading, market manipulation and other related practices. Its extensive investigatory powers include issuing subpoenae for the production of relevant evidence such as documents, and compelling suspects and others to testify in the courts. Furthermore, it has powers to:

(a) enforce civil remedies;

(b) institute administrative orders;

(c) recover any illegally obtained profits from guilty persons (disgorgement of profits);

(d) extra-territorially enforce the federal anti-fraud securities and market abuse prohibition; ${ }^{19}$

(e) provide greater incentives and immunity to whistle-blowers who report market abuse violations to the SEC;20 and

(f) impose punitive penalties on such persons and refer criminal matters to the Department of Justice. ${ }^{21}$

In 2009, the Enforcement Division created the Office of Market Intelligence, the Asset Management Unit, the Market Abuse Unit, the Structured and New Products Unit, the Foreign Corrupt Practices Act Unit and the Municipal Securities and Public Pensions Unit. This enabled the Enforcement Division to successfully minimise securities law violations by inter alia analysing and monitoring tips, complaints or referrals received by the SEC each year and to obtain enforcement actions and/or settlements consistently in a number of market abuse cases as indicated in the table 1 below.22

Table 1: Overview of the SEC's annual anti-market abuse enforcement statistics from 2001 to 2010.

\begin{tabular}{|l|l|c|c|c|c|c|c|c|c|c|c|}
\hline Enforcement Actions by Fiscal Year & $\mathbf{2 0 0 1}$ & $\mathbf{2 0 0 2}$ & $\mathbf{2 0 0 3}$ & $\mathbf{2 0 0 4}$ & $\mathbf{2 0 0 5}$ & $\mathbf{2 0 0 6}$ & $\mathbf{2 0 0 7}$ & $\mathbf{2 0 0 8}$ & $\mathbf{2 0 0 9}$ & $\mathbf{2 0 1 0}$ \\
\hline Financial Disclosure / Reporting & 112 & 163 & 199 & 179 & 185 & 138 & 219 & 154 & 143 & 126 \\
\hline Broker-Dealer & 65 & 82 & 137 & 140 & 94 & 75 & 89 & 67 & 109 & 70 \\
\hline Investment Adviser/Investment Co. & 40 & 52 & 72 & 90 & 97 & 87 & 79 & 87 & 76 & 113 \\
\hline Securities Offering & 95 & 119 & 109 & 99 & 60 & 61 & 68 & 115 & 141 & 144 \\
\hline Delinquent Filings & n/a & n/a & n/a & n/a & n/a & 91 & 52 & 113 & 92 & 106 \\
\hline Insider Trading & 57 & 59 & 50 & 42 & 50 & 46 & 47 & 61 & 37 & 53 \\
\hline Market Manipulation & 40 & 42 & 32 & 39 & 46 & 27 & 36 & 53 & 39 & 34 \\
\hline Other & $\mathbf{7 5}$ & 81 & 80 & 50 & 98 & 49 & 65 & 21 & 27 & 35 \\
\hline Total Enforcement Actions & $\mathbf{4 8 4}$ & $\mathbf{5 9 8}$ & $\mathbf{6 7 9}$ & $\mathbf{6 3 9}$ & $\mathbf{6 3 0}$ & $\mathbf{5 7 4}$ & $\mathbf{6 5 5}$ & $\mathbf{6 7 1}$ & $\mathbf{6 6 4}$ & $\mathbf{6 8 1}$ \\
\hline
\end{tabular}

Adapted from the SEC website. ${ }^{23}$

\footnotetext{
${ }^{16}$ Consequently, all trading persons or companies not regulated by other self-regulatory organisations are obliged to be registered with the NASD in order to curb all possible market abuse activities.

${ }^{17}$ Notwithstanding the existence of this merger, it is stated that the New York Stock Exchange still maintains its autonomous oversight and enforcement responsibility regarding any securities and market abuse violations which are effected on its facilities and systems by the offenders. See generally Morgan Lewis "2009 Year in Review: SEC and SRO Selected Enforcement Cases and Developments Regarding Broker-Dealers" 2010 4-6 $<$ <ttp://www.morganlewis.com/lit_SECandYearlyReviewWP_Jan2010.pdfs (accessed 10-06-2013).

18 Palmiter Securities Regulation 28-31.

${ }_{19}$ S 929P(b) read with (c) of the Dodd-Frank Wall Street Reform and Consumer Protection Act of 2010, Public Law 111-203, 124 Stat.1376 (12 USC; 55301 et seq.), hereinafter referred to as the Dodd-Frank Act; also see Morrison \& Foerster "Insider Trading" 2010 Year End Review 114-15.

${ }^{20}$ See $s 922$ of the Dodd-Frank Act which enacted s $21 \mathrm{~F}$ to repeal and replace s 21A(e) of the Securities Exchange Act; see further Morrison \& Foerster 2010 Year End Review 12-14.

${ }^{21}$ Dooley "Enforcement of Insider Trading Restrictions" 1980 Virginia Law Review 1 60-83; Carlton \& Fischel "The Regulation of Insider Trading" 1983 Stanford Law Review 857 857-895 \& Bainbridge Corporation Law and Economics (2002) 571-573.

22 Notably, this table was adapted from the SEC website <http://www.sec.gov/about/secstats2010.pdf> (accessed 30-01-2014). Over and above, the aforesaid consistent enforcement of the market abuse prohibition is supported, in part, by the fact that the SEC has established eighteen offices and eleven of these offices are regional and district offices throughout the US with approximately 3100 competent staff. Over half of the estimated 3100 SEC employees are in the Enforcement Division. This suggests that the SEC gives top priority to the effective enforcement of securities laws and combating of market abuse practices. As a result a significant number of settlements and prosecutions have to date been obtained in some landmark market abuse cases like SEC $v$ Texas Gulf Sulphur Company (1968) 401 F2d 833 (2d Cir); Dirks v SEC (1983) 463 US 646 646-655; Chiarella v United States (1980) 445 US 222; US v Martha Stewart and Peter Bacanovic (2006) 433 F3d 273; SEC v Galleon Management \& others (2009) 09 Civ 8811(SDNY); SEC v Arthur J Cutillo \& others (2009) 09 Civ 9208 (SDNY) \& SEC v Anthony Fareri \& others (2009) 09 Civ 80360 (SDFla); generally see further related analysis and/or discussion of the SEC's enforcement statistics as summarised in Morgan Lewis 2010 2-4 \& 7-13 <http://www.morganlewis.com/lit_SECandYearlyReviewWP_Jan2010.pdf> (accessed 10-06-2013).

$23<$ <ttp://www.sec.gov/about/secstats2010.pdf> (accessed 30-01-2014).
} 
In order to combat cross-border market abuse activities, the SEC entered into non-binding co-operative agreements (Memoranda of Understanding) with similar foreign securities regulatory bodies. These Memoranda of Understanding (the MOUs) permit the SEC to request such foreign regulators to investigate and provide it with certain information in circumstances in which the SEC will not be able to do so itself. ${ }^{24}$

Likewise, the SEC can also aid other foreign regulators' investigations even when no US legislation would have been violated by the occurrence of the illicit conduct in question in the US's financial markets. ${ }^{25}$ The SEC may further sanction market participants who engage in activities that are deemed illegal in other countries, even if such activities are not illegal or deemed manipulative, misleading or deceptive in the US. ${ }^{26}$ Additionally, the SEC's international co-operation and extra-territorial enforcement powers are enhanced by the fact that it is a member of the International Organisation of Securities Commissions (the IOSCO). ${ }^{27}$

As indicated above, the SEC has been very instrumental in the enforcement of the market abuse ban in the US. For instance, apart from being tasked with the responsibility to enforce the civil and administrative sanctions, the SEC supervises other participants in the securities industry and the self-regulatory organisations. This enabled the SEC to score a number of victories in the civil enforcement of market abuse in the US to date. ${ }^{28}$ Moreover, the SEC recently tightened and improved its enforcement in the aftermath of the World Com, Enron and other related market abuse cases. For example, it imposed a civil monetary fine of \$2, 25 billion on World Com in 2005 for the misuse of inside information and other related securities law violations, like corporate financial fraud. ${ }^{29}$ The SEC further imposed civil monetary fines of $\$ 250$ million on Qwest Communications, $\$ 100$ million on the Royal Dutch/Shell company and $\$ 100$ million in the Bristol-Myers Squibb case for insider trading and other related securities law violations like financial misrepresentation. ${ }^{30}$ The SEC further imposed 987 administrative sanctions (cease or desist orders, censures and suspension orders) against market abuse offenders during the period between 1978 and 2004. ${ }^{31}$ The SEC has also successfully and consistently managed to bring several enforcement actions against the insider trading offenders during the period between 2004 and 2010 as evidenced in figure 1 below. ${ }^{32}$

Figure 1: Overview of the SEC's annual insider trading enforcement statistics from 2004 to 2010.

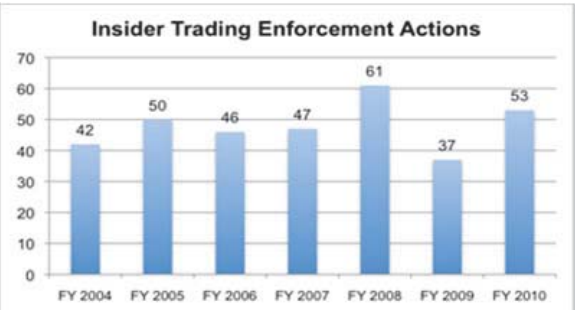

Adapted from the SEC website. ${ }^{33}$

\footnotetext{
${ }^{24}$ This co-operative enforcement at an international level has allowed the SEC to track down illicit trading and market abuse practices like offshore insider trading, secret and manipulative bank accounts in other foreign jurisdictions. See Palmiter Securities Regulation 501-502.

${ }^{25}$ S 21(a)(2) of the Securities Exchange Act.

${ }^{26}$ See generally the International Securities Enforcement Cooperation Act of 1990; s 15(b)(4)(G) of the Securities Exchange Act. Also see Palmiter Securities Regulation 502.

27 The IOSCO was founded in 1974 and is an organisation which provides guidelines on various aspects of securities enforcement and regulation to its more than 170 members. The SEC's IOSCO membership has equipped it to investigate and combat Internet-based fraud, insider trading, market manipulation and other illicit cross-border market abuse practices. See Palmiter Securities Regulation 502.

${ }^{28}$ The SEC recovered civil penalties and disgorgement fines of about \$3.3 billion from the market abuse offenders in 2006. During the period between 2002 and 2005, the SEC recovered total monetary sanctions in civil cases for market abuse ranging from approximately $\$ 5.3$ billion to $\$ 11.5$ billion. Coffee "Law and the Market: The Impact of Enforcement" 2007 University of Pennsylvania Law Review 229 230-311.

${ }^{29}$ In re World Com Inc Sec. Litig (2005) 388 F Supp 2d 319 (SDNY) 322-335, where the total settlement amount for market abuse and other related securities law violations was approximately \$6 133000000 plus interest. See further Coffee 2007 University of Pennsylvania Law Review 230-311.

${ }^{30}$ Coffee 2007 University of Pennsylvania Law Review 230-311.

${ }^{31}$ As earlier stated, the SEC has, on a number of instances, relied on its MOUs and help from fellow IOSCO member countries to track and impose appropriate sanctions against market abuse offenders in the US and other jurisdictions. See Coffee 2007 University of Pennsylvania Law Review 230-311 \& Karpoff, Lee \& Martin "The Legal Penalties for Financial Misrepresentation" (2007) <http://www.ssrn.com/abstract=933333> (accessed 28-09-2013).

32 Figure 1 was adapted from <http://www.sec.gov/spotlight/insidertrading.shtml> (accessed 30-11-2013).

33 <http://www.sec.gov/spotlight/insidertrading.shtml> (accessed 30-11-2013); notably, figure 1 indicates a relatively high number of insider trading enforcement actions that were successfully and consistently instituted against the offenders each year, from 2004 to 2010 . Also see Fons \& Rowe "The SEC Speaks: Aggressive Enforcement to Intensify in 2011" Morrison \& Foerster Client Alert 09 February 2011 1-5 \& Morgan Lewis $20107-13$ <http://www.morganlewis.com/lit_SECandYearlyReviewWP_Jan2010.pdf> (accessed 10-06-2013).
} 
On the other hand, the Financial Services Board (the FSB) ${ }^{34}$ has almost similar functions as those of the SEC. ${ }^{35}$ In other words, the FSB, like the SEC, bears the main responsibility to oversee and enforce the securities and market abuse laws in South Africa. It is not very clear whether the FSB is also statutorily responsible for enforcing the prohibition on commodities-based market manipulation in South Africa. Moreover, there is no specific regulatory body like the CFTC ${ }^{36}$ which is statutorily authorised to deal effectively and exclusively with the commodities-based market manipulation violations in South Africa. ${ }^{37}$ Strikingly, this flaw has still not been corrected by the Financial Markets Act. ${ }^{38}$ Like the SEC, ${ }^{39}$ the FSB also has quasi-legislative (rulemaking) authority. ${ }^{40}$ The FSB may, for instance, make market abuse rules after consulting with the Directorate of Market Abuse (the DMA). ${ }^{41}$

In addition, the FSB exercises administrative and supervisory authority over the DMA, the Enforcement Committee (the EC) and other relevant securities market participants. In spite of these positive developments, most of the market abuse rules that could be made by the FSB are only limited to the general manner in which its administrative powers and roles should be conducted. ${ }^{42}$ To ensure more compliance and to enhance the enforcement of the market abuse ban, the FSB delegates some of its roles to the DMA, the Johannesburg Stock Exchange Limited (the JSE) and the EC. The $D_{M A}{ }^{43}$ deals primarily with the market abuse investigations, the JSE offers surveillance support for the detection of market abuse activity and the EC oversees the enforcement of the administrative sanctions. ${ }^{44}$ Nevertheless, the FSB does not have its own surveillance systems or other mechanisms like the SEC's EDGAR ${ }^{45}$ to detect and prevent market abuse activity in the South African financial markets. ${ }^{46}$ In contrast with the SEC ${ }^{47}$ the FSB is still to employ other additional relevant measures to discourage and curb cross-border market abuse activities. ${ }^{48}$ Additionally, unlike the $\mathrm{SEC},{ }^{49}$ the FSB has not been able to investigate and/or successfully obtain timeous enforcement settlements consistently in market abuse cases as evidenced in figure 1 and table 1 below.

Figure 1: The FSB's anti-market abuse enforcement statistics from 1999 to 2010.

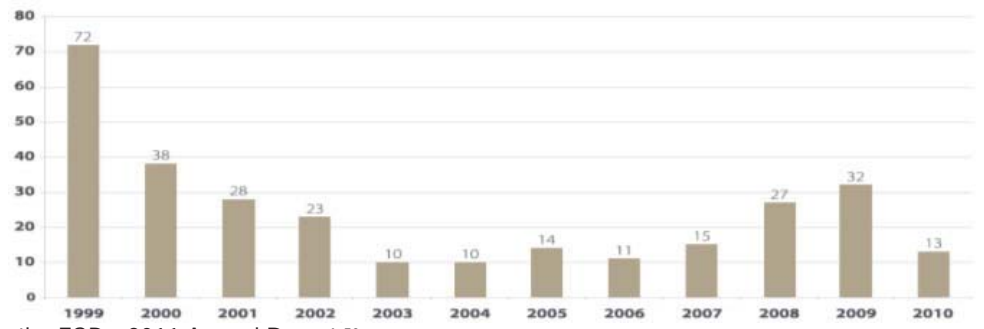

Adapted from the FSB's 2011 Annual Report. 50

\footnotetext{
${ }^{34}$ See $s$ s4 of the Financial Markets Act 19 of 2012, hereinafter referred to as the Financial Markets Act.

${ }^{35}$ See $s 84$ of the Financial Markets Act.

${ }^{36}$ See related remarks above.

${ }^{37}$ See generally ss 78; 80; 81 \& 82 of the Financial Markets Act. In relation to this, it is submitted that either the FSB or the JSE should be statutorily empowered to exclusively deal with the enforcement and prohibition of commodities-based market abuse practices in the relevant South African financial markets.

${ }^{38}$ See ss $78 ; 80 ; 81 ; 82 \& 84$

${ }^{39}$ See related remarks above.

${ }^{40} \mathrm{~S} 84(2)(f)$ of the Financial Markets Act.

${ }^{41} S$ 84(2)(f) of the Financial Markets Act.

42 Unlike the SEC, the FSB does not have express or actual authority to make (quasi-judicial powers) additional binding rules that it reasonably believe are necessary for the effective enforcement of the market abuse prohibition in South Africa. See s 84(2)(f) of the Financial Markets Act.

${ }^{43}$ See $s$ s of the Financial Markets Act.

${ }^{44}$ See $s 99$ of the Financial Markets Act \& ss 6A to 6I of the the Financial Institutions (Protection of Funds) Act 28 of 2001, hereinafter referred to as the Protection of Funds Act.

${ }^{45}$ See related remarks above.

${ }^{46}$ In relation to this, the FSB should consider following the SEC approach of devoting more competent persons to deal specifically with the enforcement of the market abuse prohibition in South Africa.

${ }^{47}$ See related remarks above.

48 Generally see the FSB Annual Report 20114 99-101; the FSB Annual Report 20133 128-130.

${ }^{49}$ See related remarks above.

50 See the FSB Annual Report 2011 99-101. Notably, figure 1 indicates a sharp and inconsistent decline in new cases of market abuse that were successfully investigated each year, from 1999 to 2010. See further the FSB Annual Report 2013 128-130.
} 
Table 1: The FSB's annual anti-market abuse enforcement statistics of new cases from 1999 to 2010.

\begin{tabular}{|l|c|c|c|c|c|c|c|c|c|c|c|c|c|c|}
\hline & 1999 & 2000 & 2001 & 2002 & 2003 & 2004 & 2005 & 2006 & 2007 & 2008 & 2009 & 2010 & Total \\
\hline Brought forward & - & 37 & 26 & 32 & 17 & 12 & 12 & 22 & 14 & 15 & 13 & 22 & 222 \\
\hline New cases & 66 & 35 & 25 & 21 & 19 & 8 & 11 & 20 & 16 & 19 & 21 & 23 & 284 \\
\hline Completed cases & $(29)$ & $(46)$ & $(19)$ & $(36)$ & $(24)$ & $(8)$ & $(1)$ & $(28)$ & $(15)$ & $(21)$ & $(12)$ & $(20)$ & $(259)$ \\
\hline Carried forward & 37 & 26 & 32 & 17 & 12 & 12 & 22 & 14 & 15 & 13 & 22 & 25 & 247 \\
\hline
\end{tabular}

Adapted from the FSB's 2011 Annual Report. ${ }^{51}$

\subsection{The Role of the Department of Justice and the Courts}

The DOJ or the federal courts have the prerogative to enforce the criminal sanctions for market abuse in the US. ${ }^{52}$ Notably, the DOJ may only prosecute any criminal cases for market abuse referred to it by the SEC. ${ }^{53}$

In spite of this referral procedure, the DOJ and the federal courts play a very important role in the enforcement of the market abuse prohibition in the US. This is supported in part by the current rigorous enforcement and prosecution of such practices in the US's competent courts. In other words, the significant number of reported cases indicates that such courts are effectively enforcing the market abuse prohibition in the US. For example, in the Drexel Burnham Lambert scandal of 1990, Kimba Wood J sentenced Michael Milken to ten years imprisonment or a criminal fine of $\$ 200$ million and ordered him to pay a $\$ 400$ million civil disgorgement of profits fine. Dennis Levine was sentenced to two years in prison, or a fine of $\$ 11,5$ million while Ivan $F$. Boesky was sentenced to three years imprisonment, or a fine of $\$ 50$ million. Milken eventually paid the criminal fine of $\$ 200$ million and $\$ 400$ million civil disgorgement profits fine. Dennis Levine paid the $\$ 11,5$ million civil disgorgement of profits fine and Ivan F. Boesky later paid the $\$ 50$ million civil disgorgement fine and an additional $\$ 50$ million civil penalty. ${ }^{54}$

In US $v$ O'Hagan ${ }^{55}$ the accused person's plea of not guilty to insider trading charges was rejected and it was held that the breach of a fiduciary duty by corporate insiders could further involve the breach of a duty of trust and confidence on the part of such insiders or other shareholders of a corporation whose securities are traded. Moreover, in The Trane Company v $0^{\prime}$ Connor Securities ${ }^{56}$ it was held that market manipulation should be discouraged and prohibited to promote open and free markets which allow natural forces of supply and demand to determine the prices of securities. This was also echoed in United States $v$ Brown, ${ }^{57}$ which postulated that market manipulation negatively affects the price of listed securities and, in so doing, it misleads and prejudices outside investors.

The successful prosecution of market abuse practices involving World Com, Martha Stewart, Tyco, Parmalat and Enron cases is further testimony of the effectiveness and competence of the US's federal courts. ${ }^{58}$ For example, the former Enron Executives, Jeffrey Skilling and Ken Lay, were convicted for insider trading and other market abuse violations. On 26 May 2006 Ken Lay was convicted on six counts of conspiracy and fraud and sentenced to 45 years in prison while Jeffrey Skilling was found guilty on 19 counts of conspiracy, fraud, making false statements and insider trading and sentenced to 185 years in prison..$^{59}$ On 23 October 2006, Skilling was criminally convicted on further counts of insider trading and sentenced to an additional imprisonment term of 25 years. The effectiveness of these courts has been made possible, in part, by the necessary governmental support and the availability resources, as well as the fact that

\footnotetext{
${ }^{51}$ See the FSB Annual Report 2011 99-101. Table 1 indicates that very few cases were successfully investigated while many cases were either brought forward or carried forward each year, from 1999 to 2010. Also see the FSB Annual Report 2013 128-130.

${ }^{52}$ Put differently, the DOJ oversees the enforcement of the criminal sanctions for market abuse by the competent federal courts. Such competent courts include the US's federal district courts, High courts and Supreme courts. Palmiter Securities Regulation 370.

${ }^{53}$ This implies that the DOJ may only institute criminal proceedings against any person who knowingly engages in market abuse practices on a referral basis. See further s 32(a) of the Securities Exchange Act.

${ }^{54}$ Tomasic "Insider Trading in the USA and United Kingdom" 1991 Australian Studies in Law, Crime and Justice Series 31 35-39.

55 (1997) 521 US 642, O'Hagan was convicted on all counts of fraud, securities violation and money laundering and sentenced to prison. Nonetheless, this conviction was later reversed by the Supreme Court on the basis that misappropriation did not violate Rule 10b-5; see further Palmiter Securities Regulation 361-362.

${ }^{56}$ (1983) 561 F Supp 301 (SDNY) 304. See further Cassim "An Analysis of Market Manipulation under the Securities Services Act 36 of 2004 (part 1)" 2008 SA Merc LJ 3337.

57 (1933) 5 F Supp 81 (SDNY) 85; 325. It was further held that the use of "wash sales" should be discouraged because it usually involves the publication of information regarding the buyer and the seller's securities transactions (share prices) which would be deceptive, false or misleading. See further Santa Fe Industries Inc v Green (1977) 430 US 462476.

${ }^{58}$ Avgouleas The Mechanics and Regulation of Market Abuse 171; 210.

${ }^{59}$ See the judgement of the US District Court SD Texas Houston Division in the case of in re Enron Corporation Securities Derivative and "ERISA"Litigation Plaintiffs v Enron Corp Oregon Corporation Defendants (2006) WL 2795321 (SD Tex).
} 
competent personnel were allocated to them. ${ }^{60}$

As highlighted above, the DOJ and the competent courts play a major role in enforcing the market abuse ban in the US. Federal courts have to date managed to radically and rigorously prosecute a number of cases involving market abuse practices like insider trading and market manipulation. ${ }^{61}$ The courts have further imposed about 2262 permanent injunctions against individuals and another 321 injunctions against companies (juristic persons) between the years 1978 and 2004. ${ }^{62}$ About 574 executive persons were barred from working as officers and directors of public corporations and 415 were barred from serving as financial professionals by both the SEC and the courts during the same period.63 Furthermore, about 755 individuals and 40 companies were indicated, 543 of the individuals were convicted and only ten were acquitted. In the same vein, the DOJ formed the Corporate Fraud Task Force (the CFTF) and consequently, a number of market abuse activities have been successfully detected and prosecuted to date. ${ }^{64}$ In light of this, one can conclude that the US has so far been fairly successful in combating market abuse and other illicit practices. Nonetheless, there is no empirical evidence that explicitly indicates that market abuse activities have either been significantly reduced or completely eradicated in the US's financial markets as a result of deterrence and/or effective enforcement. ${ }^{65}$

In contrast with the position in the US, ${ }^{66}$ it has already been pointed out that very few cases of market abuse have, to date, been successfully prosecuted and settled in South Africa. ${ }^{67}$ Moreover, unlike the US's DOJ and courts, ${ }^{68}$ the Director of Public Prosecutions (the DPP) and the competent courts in South Africa have, to some extent, struggled to obtain more convictions in market abuse cases to date. ${ }^{69}$ Notwithstanding the efforts being made by the FSB to refer the criminal cases of market abuse to the DPP for prosecution, only a few competent courts ${ }^{70}$ have jurisdiction to hear such cases. This has, to some extent, restricted or resulted in delays in the prosecution of some market abuse cases in South Africa. ${ }^{71}$ Moreover, some of the market abuse cases that were referred to the DPP by the FSB are still pending while others have either been withdrawn or abandoned, possibly because of insufficient evidence and the backlog of other cases in the relevant courts. ${ }^{72}$

\subsection{The Role of Other Selected Self-Regulatory Organisations}

Although individual persons are entitled to claim their damages directly from the offenders in private litigation, the selfregulatory organisations have to date played a key role in the civil enforcement of the market abuse prohibition and speedy provision of appropriate remedies to all the affected persons in the US.

As stated earlier, ${ }^{73}$ the SEC, through its Market Regulation Division, has a broad Congressional mandate to

60 The federal courts have also successfully prosecuted market manipulation practices. See US v Milken (1990) 759 F Supp 109 (SDNY); US v Mulheren (1991) 938 F2d 364 (2nd Cir).

${ }^{61}$ This is evidenced in part, by the successful criminal prosecution of the World Com case, where the DOJ recovered a criminal fine of $\$ 27$ million and prosecuted its CEO (Bernard Ebbers), its CFO (Scott Sullivan) and four others, resulting in combined in imprisonment terms of 32.4 years and \$49.2 million in restitution.

${ }^{62}$ Coffee 2007 University of Pennsylvania Law Review 230-311.

${ }^{63}$ Coffee 2007 University of Pennsylvania Law Review 230-311.

${ }^{64}$ The CFTF was formed in 2002 and since its inception over 1300 persons have been charged with insider trading, fraud or other related market abuse activities and about1000 were convicted. Coffee 2007 University of Pennsylvania Law Review 230-311; also see related comments and analysis contained in the press release by the DOJ "US Department of Justice, Fact Sheet: Corporate Fraud Task Force" (2006) <http://www.usdoj.gov.opa/pr/2006/August/06_odag_525.html> (accessed 12-02-2014).

${ }^{65}$ Coffee 2007 University of Pennsylvania Law Review 230-311.

${ }^{66}$ See related comments above.

${ }^{67}$ Cassim 2008 SA Merc LJ 33-37.

${ }^{68}$ See related comments above.

${ }^{69}$ Notwithstanding the fact that Bloomberg News published a story on 11 April 2007, stating that the FSB was investigating and/or has reported to the DPP the alleged market manipulation caused by an unknown American business consortium after making a substantial offer of $\$ 12,5$ billion for Gold Fields Limited resulting in 11\% increase in its shares and adding about R10 billion to the market value of Gold Fields Limited shares. See Brown "Gold Fields Zooms 11\% on Bid Talk" Business Report 12 April 2007 1. This story was unfortunately somewhat false and misleading, for example, as at 13 April 2007, the JSE had since the enactment of the Securities Services Act 36 of 2004 only referred about seven cases of market manipulation to the FSB and/or the DPP for further investigation and possible prosecution by the courts. No convictions were obtained by the South African competent courts in all these cases. This may further indicate that market abuse practices are still difficult to investigate and prosecute in South Africa. See report by Brown "FSB may Probe Bloomberg Story on Gold Fields" Business Report 13 April 2007 1; also see Cassim 2008 SA Merc LJ 34.

70 S 84(10) \& other relevant provisions of the Financial Markets Act.

${ }^{71}$ This could be worsened by the fact that the Financial Markets Act does not have provisions that empower or establish more courts to specifically adjudicate or deal with market abuse cases in South Africa. See generally s 84(10) \& other relevant provisions under Chapter X of the Financial Markets Act.

72 See the FSB Annual Report 2011 99-101; the FSB Annual Report 2013 128-130. Moreover, the DPP is still to ensure that the competent courts are manned by sufficient people with the relevant expertise in order to obtain more prosecutions and settlements in market abuse cases referred to them by the FSB.

${ }^{73}$ See paragraph 2.1 above. 
oversee the day-to-day regulation of securities market participants by the self-regulatory organisations like the NYSE, the NASD, the MSRMB and other broker-dealer companies and investment houses. ${ }^{74}$ Therefore, the SEC inspects the selfregulatory organisations and performs targeted oversight examinations of their broker-dealer members to determine whether such self-regulatory organisations are effectively supervising the financial regulations and business practices of their members. ${ }^{75}$

The NASD administers the registration of new issuers of securities and has the authority to promulgate rules governing voluntary membership of broker-dealers in over the counter markets such as the NASD Automated Quotation System. ${ }^{76}$ In order to improve the enforcement of securities laws and to curb market abuse activity among its members, the NASD divided itself into two subsidiaries, namely the NASD Regulation Inc ${ }^{77}$ and the NASD Automated Quotation System Public Market Inc. ${ }^{78}$ Each of these subsidiaries has its own independent board of directors. ${ }^{79}$ The NASD s has further authority to make rules aimed at preventing market abuse activities by market participants like research and financial market analysts. ${ }^{80}$

Moreover, the NYSE is the largest securities exchange in the US responsible for monitoring the public trading of listed securities to minimise the occurrence of potential market abuse practices in the US's financial markets. This is done by operating special computerised devices and surveillance systems to detect and prevent market abuse practices. The NYSE is further empowered to make rules or to take other action reasonably necessary to discourage market abuse activities in the US's financial markets. ${ }^{81}$

The NYSE and the NASD merged to form the Financial Industry Regulatory Authority (the FINRA) in 2007.82 In 2009, the FINRA created the Office of Fraud Detection and Market Intelligence, the Office of the Whistle-blower, the Office of Disciplinary Affairs and the Central Review Group for the speedy investigation of any suspected violations and to review tips from whistle-blowers in order to root out fraud, insider trading, market manipulation and other related market abuse practices in the US's financial markets. ${ }^{83}$

The MSRMB was established in 1975 to supervise the companies involved in the underwriting and trading of municipal securities. Although its rules are usually monitored and enforced by the SEC, the MSRMB is authorised to make its own additional market abuse enforcement rules and to impose any appropriate action against the securities laws (including State Blue Sky Laws) and market abuse violators. ${ }^{84}$

As highlighted above, it is clear that the self-regulatory organisations have contributed immensely towards the effective enforcement of securities laws to curb market abuse and other illicit trading practices in the US. In addition to the self-regulatory organisations, there are currently more than ten federal, state and industry regulatory bodies in the US. This suggests that there is good competition among the regulators to regulate certain securities products and the industry effectively and efficiently. ${ }^{85}$ Accordingly, self-regulatory organisations like the CFTC, the NASD, the NYSE and the FINRA may impose their own civil or administrative penalties against any person who violates the federal securities laws by engaging in market abuse and other illegal activities. ${ }^{86}$ This allows the US's market abuse regime to bring multiple enforcement actions against the offenders in all its financial markets. ${ }^{87}$

\footnotetext{
${ }_{74}$ Palmiter Securities Regulation 31; Hazen Federal Securities Law 5-9.

75 In other words, the SEC may approve or amend the rules of the self-regulatory organisations in accordance with the public interest and/or to enhance the combating of illicit market abuse activities like insider trading, market manipulation and the deceptive or misleading filing with the SEC, of any statements, documents or accounts. Palmiter Securities Regulation 433-434 \& 439.

${ }^{76} S$ 15(b)(8) read with s 15A of the Securities Exchange Act (as amended). Also see Palmiter Securities Regulation 404.

77 The NASD Regulation Inc oversees the regulatory functions of the NASD.

${ }^{78}$ Likewise, the NASD Automated Quotation System Public Market Inc runs the NASD Automated Quotation System.

${ }^{79}$ See Palmiter Securities Regulation 404; Lastra "The Governance Structure for Financial Regulation and Supervision in Europe" 2003 Colum J Eur L 49 53.

80 See the NASD Rule 2711; also see Palmiter Securities Regulation 414.

${ }^{81}$ See the NYSE Rule 472; also see Palmiter Securities Regulation 414; 492.

82 See generally related analysis and comments by Morgan Lewis 2010 4-6 \& 65-68 <http://www.morganlewis.com/lit_SECand YearlyReviewWP_Jan2010.pdfs (accessed 10-06-2013).

${ }^{83}$ Accordingly, about 1103 enforcement actions were successfully instituted against the offenders; 20 companies were expelled; 363 individuals were suspended and several monetary fines were recovered by the FINRA in over 73 cases during the period between 2008 and 2009. See further Morgan Lewis 2010 4-6 \& 65-69 <http://www.morganlewis.com/lit_SECandYearlyReviewWP_Jan2010.pdfs (accessed 10-06-2013); see further the FINRA "2008 Year in Review and Annual Financial Report" (2008) 9 <http://www.finra.org> (accessed 02-03-2014).

${ }^{84}$ Palmiter Securities Regulation 34-35.

${ }^{85}$ This multi-functional regulatory approach has to date resulted in far greater market abuse enforcement in the US.

${ }^{86}$ See related comments above; also see Coffee 2007 University of Pennsylvania Law Review 230-311.

${ }^{87}$ In relation to this, the CFTC has to date managed to impose a variety of sanctions on the perpetrators of commodities-based market abuse practices in the US. See the CFTC "About the Commodity Futures Trading Commission" (2006) <http://www.cftc.gov/cftcabout.htm> (accessed 07-10-2013); Also see the SEC "SEC, 2006 Performance and Accountability" (2006) Report $8<$ <ttp://www.sec.gov/about/secpar/secpar2006.pdf> (accessed 21-02-2014) \& the SEC "SEC, 2005 Performance and Accountability" (2005) Report 7 <http://www.sec.gov/about/secpar/secpar2005.pdf> (accessed 21-02-2014).
} 
In South Africa, apart from the FSB and its committees, other regulatory bodies like the JSE may also enforce the market abuse ban. Accordingly, like the SEC, 88 the FSB may exercise supervisory authority over all the regulatory bodies that deal with market abuse in South Africa. ${ }^{89}$ In the same vein, as stated before, ${ }^{90}$ the FSB has a prerogative to make market abuse rules that govern the enforcement of market abuse laws in South Africa. ${ }^{91}$ Apart from the FSB and the JSE, there are no self-regulatory organisations that are specifically responsible for enforcing market abuse laws in South Africa. ${ }^{92}$ In relation to this, there is no specific provision in the Financial Markets Act which empowers other self-regulatory organisations to enforce the market abuse ban in South Africa. ${ }^{93}$ While this approach is good in that it minimises bureaucracy, balkanisation, conflict of interests and confusion that may be associated with many regulatory bodies and self-regulatory organisations, it has not been fully utilised to obtain more settlements and prosecutions of market abuse cases in South Africa to date. ${ }^{94}$

\section{Concluding Remarks}

The article has revealed that both the US and the South African market abuse regimes maintain similar enforcement goals and missions. ${ }^{95}$ In spite of this, they adopt and implement very different approaches to achieve their enforcement goals and/or targets. Put differently, the US's anti-market abuse enforcement framework employs the multi-functional regulatory approach which offers competition among the regulatory authorities at a federal level, ${ }^{96}$ but nevertheless resulting in far greater and effective enforcement. Moreover, the US's anti-market abuse enforcement framework provides the much needed resources, competent personnel in the courts and the SEC as well as better technological surveillance mechanisms to detect illicit trading practices. ${ }^{97}$

On the contrary, notwithstanding the fact that the South African market abuse legislation was relatively influenced by the corresponding legislation in the US, it sometimes lacks a rigorous practical enforcement approach and infrastructure to combat market abuse activities ${ }^{98}$ Consequently, it is submitted that the DPP should introduce more specialised courts or tribunals that are staffed with judges and other persons with the relevant expertise to hear and/or prosecute market abuse cases in South Africa timeously and effectively. Furthermore, the Protection of Funds Act and/or the Financial Markets Act should be reviewed to enact provisions that expressly empower the EC to make its own market abuse rules to enhance the combating of market abuse practices in South Africa. Lastly, notwithstanding the potentially negative effects of bureaucracy, balkanisation and conflict of interests that may be associated with many regulatory bodies, it is submitted that more self-regulatory organisations should be statutorily empowered to impose their own penalties and/or take any other appropriate action against market abuse offenders in South Africa.

\section{References}

Books

Arshadi N \& Eyssell TH The Law and Finance of Corporate Insider Trading: Theory and Evidence (Kluwer Academic Publishers Massachusetts 1993)

Ashe TM \& Counsell L Insider Trading: The Tangled Web (Fourmat Publishing London 1990)

Avgouleas E The Mechanics and Regulation of Market Abuse: A legal and Economic Analysis (Oxford University Press Oxford 2005)

Bainbridge SM Corporation Law and Economics (Foundation Press New York 2002)

Beuthin RC and Luiz SM Beuthin's Basic Company Law 3rd ed (Butterworths Durban 2000)

Hazen TL The Law of Securities Regulation: Handbook Series Student Edition (West Publishing Company St Paul, MN 1985)

\footnotetext{
${ }^{88}$ See paragraph 2.1 \& other related remarks above.

${ }^{89}$ See related remarks in paragraph 2.1 above.

${ }^{90}$ See related remarks in paragraph 2.1 above.

${ }^{1} \mathrm{~S}$ 84(2)(f) of the Financial Markets Act. This implies that other regulatory bodies like the DMA do not have express statutory authority to make their own independent market abuse rules regarding the enforcement of market abuse laws in South Africa.

92 The Financial Markets Act mainly empowers only the FSB to police the regulation and enforcement of market abuse ban in South Africa. See s 84.

${ }^{93}$ See relevant provisions in Chapter $X$ entitled Market Abuse of the Financial Markets Act.

${ }^{94}$ See related remarks in paragraphs $2.1 \& 2.2$ above.

${ }^{95}$ See paragraphs 2.1; $2.2 \& 2.3$ above.

${ }^{96}$ See paragraph 2.3 read with paragraphs $2.1 \& 2.2$ above.

${ }^{97}$ This enhanced and contributed significantly to the success achieved by the US in the enforcement of the market abuse laws as indicated by a considerable number of cases that were reported and successfully settled or prosecuted to date. See further SEC v Texas Gulf Sulphur Company 833; Dirks v SEC 646-655; United States v O'Hagan 2199; United States v Falcone 91489 \& SEC v Yun 1263; SEC v One or more purchasers of call options for the Common Stock of CNS INC (2006) US District Court 3004875 WL (EDPa) \& Dolgopolov "Insider Trading and the Bid-Ask Spread: A Critical Evaluation of Adverse Selection in Market Making" 2004 Capital University Law Review 8384.

${ }^{98}$ See paragraph 2.2 read with paragraphs $2.1 \& 2.3$ above.
} 
Hazen TL Federal Securities Law 2nd ed (Federal Judicial Center United States of America 2003)

Lyon GJ \& Du Plessis JJ The Law of Insider Trading in Australia (The Federation Press Sydney 2005)

Palmiter AR Securities Regulation: Examples and Explanations $3^{\text {rd }}$ ed (Aspen Publishers New York 2005)

Swan EJ Market Abuse Regulation $1^{\text {st }}$ ed (Oxford University Press United States of America 2006)

Journal articles

Bhattacharya U \& Daouk H "The World Price of Insider Trading" 2002 Journal of Finance 75-108

Botha D "Control of Insider Trading in South Africa: A Comparative Analysis" 1991 SA Merc LJ 1-18

Botha D "Increased Maximum Fine for Insider Trading: A Realistic and Effective Deterrent?" 1990 SALJ 504-508

Carlton DW \& Fischel DR "The Regulation of Insider Trading" 1983 Stanford Law Review 857-895

Cassim R "An Analysis of Market Manipulation under the Securities Services Act 36 of 2004 (Part 1)" 2008 SA Merc LJ 33-60

Cassim R "An Analysis of Market Manipulation under the Securities Services Act 36 of 2004 (Part 2)" 2008 SA Merc LJ 177-199

Coffee JC "Law and the Market: The Impact of Enforcement" 2007 University of Pennsylvania Law Review 229-311

Dolgopolov S "Insider Trading and the Bid-Ask Spread: A Critical Evaluation of Adverse Selection in Market Making" 2004 Capital University Law Review 83-180

Dooley MP "Enforcement of Insider Trading Restrictions" 1980 Virginia Law Review 1-83

Friedman HM "The Insider Trading and Securities Fraud Enforcement Act of 1988" 1990 North Carolina Law Review 465-494

Gilson RJ \& Kraakman RH "The Mechanisms of Market Efficiency" 1984 VA.L.REV 549-644

Henning JJ \& Du Toit S "The Regulation of False Trading, Market Manipulation and Insider Trading" 2000 Journal for Juridical Science $155-165$

Horwich A "The Origin, Application, Validity and Potential Misuse of Rule 10b5-1" 2007 The Bus. Lawyer 913-954

Jooste R "A critique of the insider trading provisions of the 2004 Securities Services Act" 2006 SALJ 437-460

Kaswell SJ "An Insider's View of the Insider Trading and Securities Fraud Enforcement Act" 1989 Bus.Law 145-180

Knepper ZT "Examining the Merits of Dual Regulation for Single-Stock Futures: How the Divergent Insider Trading Regimes for Federal Futures and Securities Markets Demonstrate the Necessity for (and Virtual Inevitability of) Dual CFTC-SEC Regulation for SingleStock Futures" 2004 Pierce Law Review 33-47

Langevoort DC \& Gulati GM "The Muddled Duty to Disclose under Rule 10b-5" 2004 Vand L Rev 1639-1680

Lastra RM "The Governance Structure for Financial Regulation and Supervision in Europe" 2003 Colum J Eur L 49-68

Luiz SM "Insider Trading Regulation - If at First You Don't Succeed..." 1999 SA Merc LJ 136-151

Luiz SM "Market Abuse and the Enforcement Committee" 2011 SA Merc LJ 151-172

Osode PC "The new South African Insider Trading Act: Sound law reform or legislative overkill?" 2000 Journal of African Law 239-263

Osode PC "The Regulation of Insider Trading in South Africa: A Public Choice Perspective" 1999 African Journal of International and Comparative Law 688-708

Markham JW "'Front-Running'-Insider Trading under the Commodity Exchange Act" 1988 Cath.U.Review 69-127

Mossos E "Sarbanes-Oxley goes to Europe: A Comparative Analysis of United States and European Union Corporate Reforms after Enron" 2004 Currents International Trade Law Journal 9-22

Nelemans M "Redefining Trade-Based Market Manipulation" 2008 Valparaiso University Law Review 1169-1220

Osode PC "The new South African Insider Trading Act: Sound law reform or legislative overkill?" 2000 Journal of African Law 239-263

Pearce BD "Broadening Actual Damages in the Context of the Commodities Exchange Act" 2007 Journal of Law and Policy 449-483

Pearson TC "When Hedge Funds Betray A Creditor Committee's Fiduciary Role: New Twists on Insider Trading in the International Financial Markets" 2009 Review of Banking \& Financial Law 165-220

Ryan L "Rule14e-3's Disclose or Abstain Rule and Its Validity under Section 14(e)" 1991 U. Cin. Law Review 449-465

Steinberg MI "Insider Trading Regulation-A Comparative Perspective" 2003 The International Lawyer 153-171

Tomasic R "Insider Trading in the USA and United Kingdom" 1991 Australian Studies in Law, Crime and Justice Series 31-39

Van Deventer G "New watchdog for insider trading" 1999 FSB Bulletin 2-3

Van Deventer G "Harnassing Administrative Law in Encouraging Compliance" 2009 FSB Bulletin 3-4

Case law

South Africa

Pretorius and Another v Natal South Sea Investment Trust 19653 SA 410 (W)

United States of America

Cady, Roberts and Company [1961-1964 Transfer Binder] CCH Fed Sec L Rep 76. 803

Chiarella v United States (1980) 445 US 222

Dirks v SEC (1983) 463 US 646

FMC Corp v Boesky (1988) 852 F2d 981 ( $7^{\text {th }}$ Cir)

FMC Corp v Boesky (1987) 673 F2d 272 (ND I11)

In re Enron Corporation Securities Derivative and "ERISA"Litigation Plaintiffs v Enron Corp Oregon Corporation Defendants (2006) WL 2795321 (SD Tex)

In re World Com Inc Sec. Litig (2005) 388 F Supp 2d 319 (SDNY) 
Santa Fe Industries Inc v Green (1977) 430 US 462

SEC $v$ Anthony Fareri \& others (2009) 09 Civ 80360 (SDFla)

SEC v Arthur J Cutillo \& others (2009) 09 Civ 9208 (SDNY)

SEC v Boesky (1986) 86 Civ 8767

SEC $v$ Galleon Management \& others (2009) 09 Civ 8811(SDNY)

SEC v Levine (1986) 86 Civ 3726 (SDNY) (RO)

SEC $v$ One or more purchasers of call options for the Common Stock of CNS INC (2006) US District Court 3004875 WL (EDPa)

SEC v Texas Gulf Sulphur Company (1968) 401 F2d 833 (2d Cir)

SEC v WorldCom Inc (2003) 02 Civ 4963(JSR)

SEC v Yun (2003) $327 \mathrm{~F} 3 \mathrm{~d} 1263$ (11 ${ }^{\text {th }}$ Cir)

The Trane Company v O'Connor Securities (1983) 561 F Supp 301 (SDNY)

United States v Brown (1933) 5 F Supp 81 (SDNY)

United States v Chestman (1991) 947 F2d 551 (2d Cir)

United States v Falcone [2001 Transfer Binder] 91489 Fed Sec L Rep CCH (2d Cir)

United States v O'Hagan (1997) 117 (SCt) 2199

US v Martha Stewart and Peter Bacanovic (2006) 433 F3d 273

US v Milken (1990) 759 F Supp 109 (SDNY)

US v Mulheren (1991) $938 \mathrm{~F} 2 \mathrm{~d} 364$ ( $\left.2^{\text {nd }} \mathrm{Cir}\right)$

US v O'Hagan (1997) 521 US 642

Legislation

South Africa

Companies Act 61 of 1973

Companies Act 71 of 2008

Consumer Protection Act 68 of 2008

Financial Markets Act 19 of 2012

Financial Institutions (Protection of Funds) Act 28 of 2001

United States of America

Commodity Exchange Act of 19367 USC 1 et seq. (1994)

Commodities Futures Modernization Act 2000 Public Law 106-554, 114 Stat.2763A-365

Commodity Futures Trading Commission Act of 1974 Public Law 93-64, 88 Stat 1398

Derivatives Market Manipulation Prevention Act of 2009

Dodd-Frank Wall Street Reform and Consumer Protection Act of 2010, Public Law 111-203, 124 Stat.1376 (12 USC; s 5301 et seq.)

Insider Trading and Securities Fraud Enforcement Act of 1988 Public Law 100-704, 102 Stat 4677

Insider Trading Sanctions Act of 1984 Public Law 98-376, 98 Stat.1264 (1984)

International Securities Enforcement Cooperation Act of 1990

Investment Advisors Act of 1940

Investment Company Act of 1940

Public Company Accounting Reform and Investor Protection Act of 2002 Public Law 107-204, 116 Stat 745 (15; 28 USC)

Public Utility Holding Company Act of 1935

Racketeer Influenced and Corrupt Organization Act of 1970

Securities Act of 1933 Public Law 2248 Stat 7415 USC77a-77mm (1994)

Securities Act of 1933, Public Law 2248 Stat.74 15 USC 77a-77mm et seq. (2000)

Securities Act of 193315 USC 77q(a) (2006) as amended by PL-111-229 (approved 11-08-2010)

Securities Exchange Act of 1934 Public Law 73-291, 48 Stat 88115 USC 78a-78II

Securities Exchange Act of 193415 USC 78i(a)(2)-(5) (2006) as amended by PL-111-257 (approved 05-10-2010)

Securities Exchange Act Release Number 43154 [2000 Transfer Binder] Fed Sec L Rep CCH 86.319

Trust Indenture Act of 1939

Commissions, committees and reports

South Africa

Financial Services Board Annual Report 2011

Financial Services Board Annual Report 2013

United States of America

The Commodity Futures Trading Commission \& the United States Securities and Exchange Commission "A Joint Report of the SEC and the CFTC on Harmonization of Regulation" Report 16 October 2009

Thesis and dissertations 
Chitimira H A Comparative Analysis of the Enforcement of Market Abuse Provisions (LLD-thesis Nelson Mandela Metropolitan University 2012)

Chitimira H The Regulation of Insider Trading in South Africa: A Roadmap for an Effective, Competitive and Adequate Regulatory Statutory Framework (LLM-dissertation University of Fort Hare 2008)

Conference papers, media releases and other relevant material

Fons RJ \& Rowe TA "The SEC Speaks: Aggressive Enforcement to Intensify in 2011" Morrison \& Foerster Client Alert 09 February 2011 Morrison \& Foerster "Insider Trading" 2010 Year End Review 1

\section{Newspaper reports}

Brown J "Gold Fields Zooms 11\% on Bid Talk" Business Report 12 April 2007

Brown J "FSB may Probe Bloomberg Story on Gold Fields" Business Report 13 April 2007

Chanetsa B "Insider Trading is Notoriously Hard to Prosecute" Business Report 26 April 2004

Internet sources

Commodity Futures Trading Commission "About the Commodity Futures Trading Commission" (2006) <http://www.cftc.gov /cftcabout.htm> (accessed 07-10-2013)

Department of Justice "US Department of Justice, Fact Sheet: Corporate Fraud Task Force" (2006) <http://www.usdoj.gov.opa /pr/2006/August/06_odag_525.html> (accessed 12-02-2014)

Financial Industry Regulatory Authority "2008 Year in Review and Annual Financial Report" (2008) <http://www.finra.org> (accessed 0203-2014)

Financial Services Board "Enforcement Committee Actions" Media Release (28-06-2011) <http://www.fsb.co.za/ftp://ftp.fsb.co.za /public/documents/AReport2011.pdf> (accessed 22-11-2013)

Financial Services Board "List of Current Investigations of the Directorate of Market Abuse" Media Release (28-06-2011) $<$ http://www.fsb.co.za/ftp://ftp.fsb.co.za/public/documents/AReport2011.pdf> (accessed 22-11-2013)

Karpoff JM, Lee DS \& Martin GS "The Legal Penalties for Financial Misrepresentation" (2007) <http://www.ssrn.com/abstract=933333> (accessed 28-09-2013)

Morgan Lewis "2009 Year in Review: SEC and SRO Selected Enforcement Cases and Developments Regarding Broker-Dealers" 2010 $<$ <ttp://www.morganlewis.com/lit_SECandYearlyReviewWP_Jan2010.pdf> (accessed 10-06-2013)

Myburgh A \& Davis B "The Impact of South Africa's Insider Trading Regime: A Report for the Financial Services Board" (25-03-2004) <http://www.genesis-analytics.com/public/FSBReport.pdf> (accessed 09-02-2013)

United States Securities and Exchange Commission "SEC, 2006 Performance and Accountability" (2006) Report 8 <http://www.sec.gov labout/secpar/secpar2006.pdf> (accessed 21-02-2014)

United States Securities and Exchange Commission "SEC, 2005 Performance and Accountability" (2005) Report 7 <http://www.sec.gov labout/secpar/secpar2005.pdf> (accessed 21-02-2014)

Van Deventer G "Anti-Market Abuse Legislation in South Africa" (10-06-2008) <http://www.fsb.co.za/public/marketabuse/FSBReport.pdfs (accessed 05-05-2013) 